Article

\title{
Decision-Making Methodology for Risk Management Applied to Imja Lake in Nepal
}

\author{
Amanda D. Cuellar * and Daene C. McKinney \\ Department of Civil Architectural and Environmental Engineering, University of Texas at Austin, \\ Austin, TX 78712, USA; daene@aol.com \\ * Correspondence: adcuellar.tlax@gmail.com; Tel.: +1-254-644-5410
}

Received: 8 June 2017; Accepted: 2 August 2017; Published: 8 August 2017

\begin{abstract}
Glacial retreat causes the formation of glacier lakes with the potential of producing glacial lake outburst floods (GLOFs). Imja Lake in Nepal is considered at risk for a GLOF. Communities in the path of a potential Imja GLOF are implementing adaptation projects, yet no quantitative data or guidance is available to understand the benefits of these projects or how to weigh benefits against the cost of implementation. We develop and demonstrate a decision-making methodology for GLOF risk management, incorporating available scientific information and uncertainty. The methodology consists of (1) identifying flooding scenarios, (2) evaluating scenario consequences, and (3) performing an economic analysis of proposed adaptation projects. The methodology is applied to assess benefits in Dingboche of lowering Imja Lake by 3, 10 and $20 \mathrm{~m}$. The results show that the baseline case (no lake lowering) has the lowest expected cost because of low valuation of agricultural land and homes in the literature. Nonetheless, the result is sensitive to changes in the analysis variables. We also found that lowering the lake by 10 or $20 \mathrm{~m}$ is efficient according only to the methodology used here; however, considering only direct economic damages and literature cost estimates, the costs outweigh the benefits for these projects.
\end{abstract}

Keywords: glacial lake outburst flood; risk management; decision making; Imja Lake; data envelopment analysis; decision analysis

\section{Introduction}

High altitude glaciated regions have experienced glacial retreat since the end of the Little Ice Age [1,2]. The effects of a changing climate have accelerated the process of glacial lake formation and growth [3-6]. As glaciers retreat, melt water often collects at the base of the ice behind a natural dam (termed moraine) of rocks, soil and debris pushed forward by the previously expanding glacier [7]. Terminal moraines tend to be unstable [8], in part because they often contain ice that is also melting [7]. When a terminal moraine fails, say because of pressure from the growing lake, an avalanche triggered wave or an earthquake, the sudden outflow of water can cause devastation to downstream communities and infrastructure $[4,6,7,9-12]$.

The threat of a glacial lake outburst flood (GLOF) results from the complex interactions of multiple physical phenomena. Stability of the slopes above the glacial lake and of the moraines (terminal and lateral), dynamics of the glacier and lake over time and hydrodynamics in the lake and of the flood downstream converge to produce a GLOF event $[5,7,13]$. Understanding and predicting the chain of events that lead to a GLOF is highly complex and uncertain. To predict a future GLOF, researchers must model the triggering mechanism, possible moraine erosion and breach, and downstream inundation through often poorly surveyed valleys $[9,12,14-16]$. These difficulties have led researchers to rely on simplified models and approximations to overcome high complexity and lack of data [12]. All of these components contribute to the uncertainty of a GLOF simulation. Further complicating the prediction is 
the evolution of glaciers and the lakes they feed (including the complex role of climate change) [3,17]. Therefore, the resulting models are uncertain and focus on simulating a given flood scenario rather than trying to predict the most likely chain of events.

GLOF risk mitigation works usually consist of draining water from a glacial lake, thus lowering the lake level [7]. By lowering the lake level, pressure on the moraine decreases and the potential surge of water flowing downstream in the event of a flood is decreased, resulting in a smaller inundated area $[7,13,18]$. A less costly and invasive option is to install early warning systems and community outreach efforts. Lake lowering has been a preferred method of GLOF mitigation (versus relocation of the population or early warning systems) as it does not require much maintenance and allows the community to retain its current location and practices [2,7]; however, future changes in and condition of glacial lakes need to be considered.

Successful GLOF mitigation works have been installed in Nepal previously at Tsho Rolpa in $2000[2,19]$ and at Imja Lake in 2016 [20,21]. Works to lower the level of Imja Lake in Nepal by $3.4 \mathrm{~m}$ have recently been implemented [21], as has an early warning system to alert communities of a GLOF.

Although researchers have made significant advances in understanding and modeling GLOF scenarios from Imja Lake $[17,22,23]$, the information has not been analyzed with risk assessment or decision making in mind. In particular, only one study has attempted to quantify possible GLOF inundation severity from Imja Lake with various levels of lake lowering remediation [18]. In addition, no other work has quantified the range of potential fatalities or direct economic impacts of an Imja Lake GLOF with and without mitigation measures. Other researchers have estimated direct and secondary economic damages from an Imja GLOF $([2,22])$; however, they did not estimate the benefits of GLOF risk mitigation projects. Finally, researchers have not proposed a means for evaluating the costs and benefits of various adaptation options that considers the available data and reflects the extreme uncertainty surrounding GLOF prediction. The risk management methodology presented here and applied to Imja Lake in Nepal consists of a series of analytical procedures meant to quantitatively include the existing knowledge regarding GLOF risks, reflect the uncertainty regarding the occurrence, timing, and characteristics of a flood, and allow for incorporation of stakeholder concerns. Through this analytical framework, we seek to understand the costs and benefits of GLOF risk mitigation works and provide information to help guide decision makers as they consider the various options.

In this paper, we estimate damage from a potential Imja Lake GLOF to people and infrastructure downstream with and without mitigation measures, identify economically efficient mitigation projects considering intangible damages from a GLOF, and identify the least expected cost project taking into account uncertainty in the timing and occurrence of a GLOF. This work demonstrates the decision-making methodology using published and readily available data (data on inhabitants is the exception as it was gathered from a satellite and field inventory) as updating and repeating scientific studies of Imja Lake is beyond the scope of this study. Likewise, conducting local studies to determine community valuation of at-risk infrastructure is beyond the scope of this work, though such information is not incompatible with the methodology presented here. In order to produce actionable results in communities at risk for an Imja GLOF, community consultations should be undertaken to establish how local inhabitants value the at-risk infrastructure. This framework would be very useful as decision makers plan how to allocate funds for glacial lake risk management projects. The type of decision makers who would benefit from this study include, for example, the Nepal Department of Hydrology and Meteorology and the UNDP, since they are in the process of preparing several new glacial lake mitigation projects in Nepal. In addition, this method could be useful for decision makers in other countries facing GLOF mitigation needs.

\section{Study Area}

Imja Lake is in the Khumbu region of Nepal close to the Nepalese border with Tibet $\left(27^{\circ} 53^{\prime} 53^{\prime \prime} \mathrm{N}\right.$, $86^{\circ} 55^{\prime} 41^{\prime \prime} \mathrm{E}$ ) and on one of the most popular trekking routes to Mt. Everest (Figure 1). Several communities exist in the region and rely on agriculture and tourism for their income [18]. In this study, 
we focus on the community of Dingboche, which is approximately $7 \mathrm{~km}$ downstream from Imja Lake. The Lhotse Shar, Imja, and Amphulapcha glaciers contribute to Imja Lake, which is part of the Imja Khola watershed. Outflow from Imja Lake drains to the Imja Khola river, which is a tributary of the Dudh Khosi.

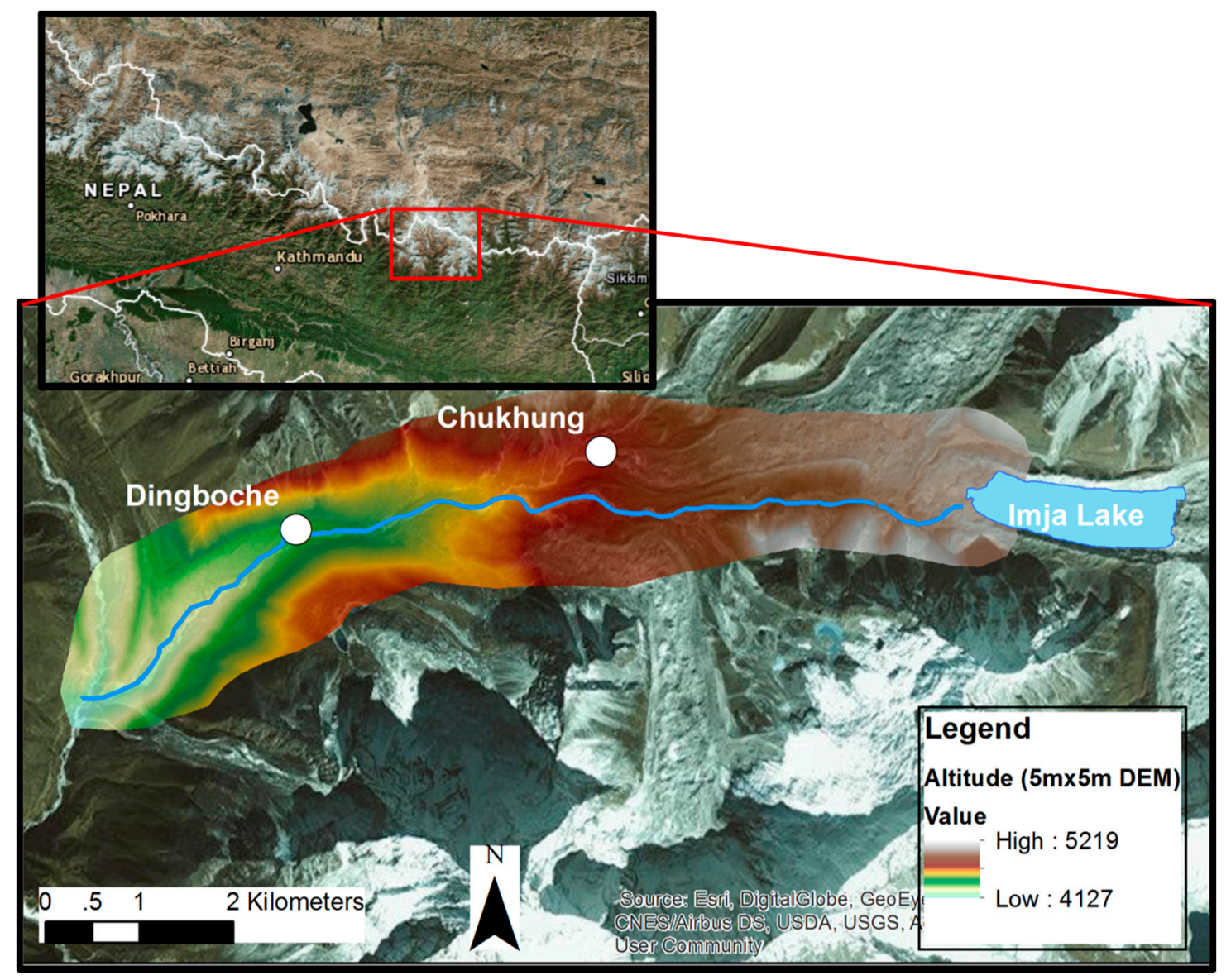

Figure 1. Map of Imja Lake and downstream communities in the Khumbu region of the Himalaya, Nepal.

In the 1960s, Imja Lake was a collection of melt ponds on the surface of Imja glacier. However, by 1984, the lake measured approximately $0.4 \mathrm{~km}^{2}$ and had grown to $1.257 \pm 0.104 \mathrm{~km}^{2}$ in 2012 [24,25]. A detailed study of Imja Lake and Imja Glacier's evolution from the 1960s to 2013 found that lake appearance and growth corresponded to shrinkage of the glacier [26]. The study concluded that rapid changes to Imja Glacier and lake can be attributed to higher temperatures in post-monsoon months driving higher ablation of the glacier near the lake [26]. Imja Lake's rapid rate of growth, physical characteristics, and possible moraine instability have raised concern that the lake poses a high potential for an outburst flood $[2,18,27,28]$. Nonetheless, several studies have also found that the potential for a GLOF from Imja Lake is lower than previously thought [29-31]. Rounce et al. [23], found that Imja Lake was of moderate risk at that time due to its low hazard ranking and high downstream impact potential, but that the hazard and risk of the lake will likely increase over the next few decades if the lake continues to grow at its current rate. Despite the disagreement over the danger posed by Imja Lake, researchers have conducted numerous studies to understand how a GLOF from the lake would affect areas downstream [2,18,23]. Other studies of the lake have also focused on lake characteristics [25], moraine and glacier characteristics [31], and melting of source glaciers [32]. Recent field studies of the lake have found water seeping through the moraine and studies of satellite imagery show that the lake continues to grow toward the source glacier $[18,23,30]$, which raises concern about 
the lake's safety. Additionally, ground penetrating radar and electrical resistivity tomography studies have identified dead ice in the lake's terminal moraine, which can melt as temperatures rise and cause instability $[29,31,33]$. The observed seepage indicates piping of water through the moraine and instability of the terminal moraine. These two features suggest that a likely GLOF trigger at Imja Lake is self-destructive moraine failure [23]. Given that the lake is significantly removed from surrounding steep slopes and therefore unlikely to experience a GLOF due to an avalanche induced wave, the moraine collapse failure mode is the only GLOF trigger considered in this analysis.

This study relies on the modeling of potential GLOFs from Imja Lake published in Somos-Valenzuela et al. [18], before lake lowering. The recent lake lowering works have likely changed the risk of a GLOF and dynamics of a future event, although these effects have not been studied at the time of publication. A recent study found that Imja Lake poses a moderate risk at present and that as the lake expands in the coming decades it will pose a higher hazard and risk [34].

\section{Methods}

The risk management methodology, shown in Figure 2, consists of five steps that are elaborated in the following sections: (1) likely GLOF and lake lowering scenarios are identified; (2) the consequences (damages) of each potential flood event and lake lowering scenario are estimated using field and satellite data to fill knowledge gaps; (3) decision analysis (DA) is used to identify the lowest cost lake lowering projects; (4) the data envelopment analysis (DEA) and DA methods are combined to determine project efficiency taking into account the limited data and uncertainty surrounding a GLOF from Imja Lake.

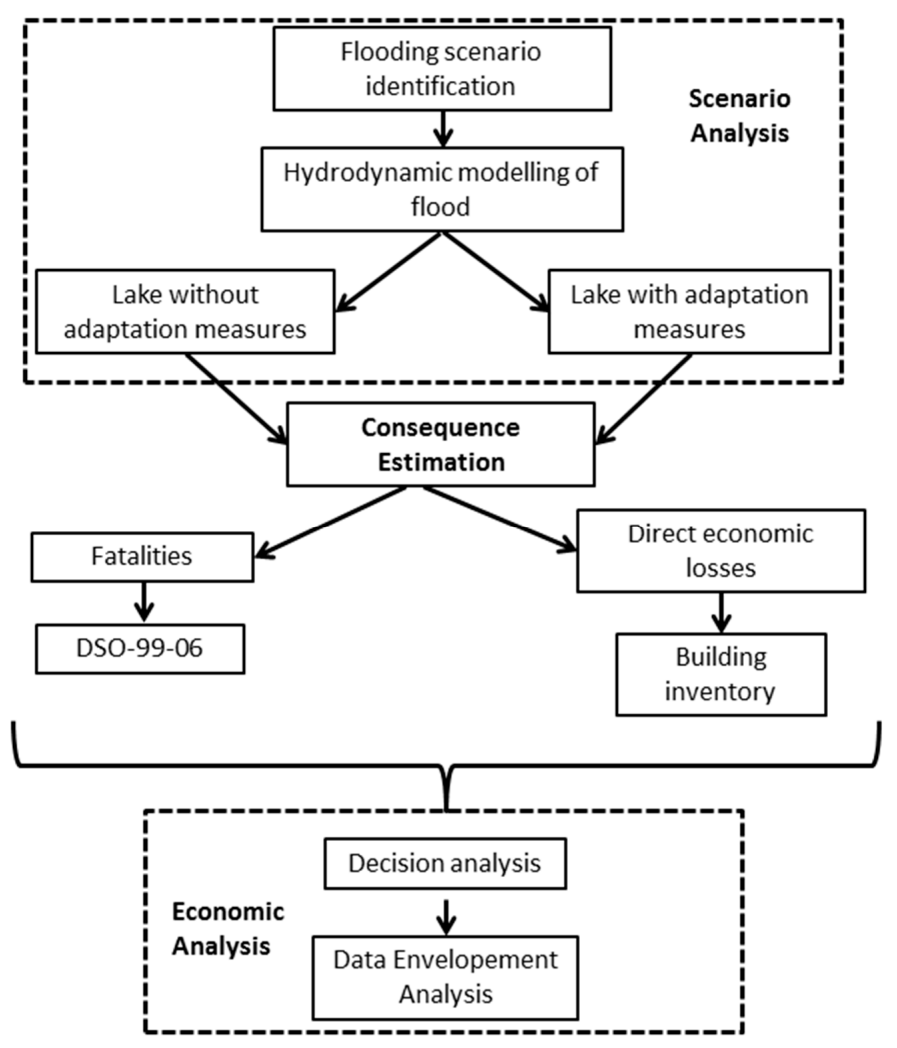

Figure 2. The glacial lake outburst flood (GLOF) risk management methodology.

\subsection{Scenario Identification}

The first step of the analysis is to identify potential GLOF scenarios and mitigation projects. Model results of a GLOF due to moraine failure at Imja Lake with and without a lake lowering project 
were used [18]. A business as usual (BAU) scenario was used that assumes no change is made to the lake; that is, with lake conditions before the 2016 lowering project was implemented. The GLOF mitigation works considered included lowering Imja Lake by 3, 10, and $20 \mathrm{~m}$, with $3.4 \mathrm{~m}$ lowering being the currently implemented project. Modeling has shown that lowering the lake by $10 \mathrm{~m}$ results in a significant decrease in damage to the nearest downstream community of Dingboche (about $7 \mathrm{~km}$ below the lake), and lowering the lake by 20 m nearly eliminates damage in Dingboche [18].

\subsection{Damage Estimation}

For this analysis, direct damage from a GLOF to the Dingboche-Imja Lake trekking trail, Dingboche residents, homes, buildings, and agricultural land were considered. Indirect economic damages, valuation of damage to property other than structures, long term damages, and the intangible harm to local society (such as culture, health and well-being) were not considered here due to lack of data and because quantifying such damages is beyond the scope of this work. In addition to GLOF consequences, the cost of implementing various flood mitigation projects was estimated. Data for damage estimation was gathered through field inventories, literature sources, and analysis of satellite imagery.

A building inventory of Dingboche was developed using a combination of satellite imagery and field inventories. Initially, satellite imagery from ArcGIS (high resolution World Imagery) [35], Google Earth [36], and Digital Globe imagery [37] was used to identify buildings in the flood plain to inventory in the field. Field inventories were conducted to confirm the initial building inventory during a visit to the area in October 2015. A total of 50 points that had been identified in the initial building inventory were verified. The field inventory confirmed the presence of buildings, the type (home, shed, etc.), the number of building occupants, and whether the building was inhabited seasonally or year-around.

In addition to buildings and inhabitants, damage to agricultural land and to the Dingboche-Imja Lake trekking trail was considered. Agriculture and tourism are important economic activities in the region [38]. The area of agricultural land in the GLOF flood plain was estimated previously by Somos-Valenzuela et al. [18]. The Dingboche-Imja Lake trekking trail leads to the base camp of Island Peak, a popular trekking peak near Mt. Everest. The trail location was exported from Google Maps [39] and from datasets provided by the Sagarmatha National Park for use in this analysis.

Damage to infrastructure was estimated by overlapping the inundated area with the buildings, agricultural lands, and trekking trail maps. It was assumed that if infrastructure was in the path of the GLOF it would be damaged. However, the extent of damage was not estimated. Given the limited information about the conditions of infrastructure and its ability to resist flood waters, the level of damage cannot be confidently estimated. Fatalities were estimated using the U.S. Bureau of Reclamation empirical method DSO-99-06 [40], which provides fatality rates (estimated from historical events) depending on the flood severity, warning time and the public's understanding of flood severity. Considering the recent construction of a GLOF warning system in Dingboche, we estimated fatalities given the expected warning time (about $20 \mathrm{~min}$ ) and level of severity understanding in the cases where data is available (for the DSO-99-06 method, there must be a historical case of a flood event matching the characteristics of the modeled flood).

DSO-99-06 provides a method for estimating the flood severity depending on discharge per unit width of flow (maximum depth times maximum velocity, $\mathrm{d} \times \mathrm{v}$ ), mean annual discharge, and discharge after dam failure [40]. Flood severity is also described qualitatively by the level of damage to buildings. Because DSO-99-06 flood severity estimates are not specific to the construction methods in less developed regions of the world, we use the flood intensity classifications developed from observing debris flow damage in Venezuela [41]. The damage in each intensity category of Garcia-Martinez and Lopez matches the event intensity damage to buildings described in DSO-99-06 [40] (Table 1). Based on the results of the FLO-2D modeling of a potential Imja GLOF conducted by Somos-Valenzuela et al. [18], the areas of Dingboche that would experience high, medium and low debris flow intensities were identified. 
Table 1. Debris flow event intensity, flood severity characteristics, and fatality rates (data from Garcia-Martinez and Lopez (2007) [41] and Graham (1999) [40]).

\begin{tabular}{|c|c|c|c|c|c|}
\hline \multirow{3}{*}{ Event Intensity } & \multicolumn{4}{|c|}{ Flood Severity Characteristics } & \multirow{3}{*}{$\begin{array}{c}\text { Fatality Rate with 15-60 min. } \\
\text { Warning, Vague Understanding } \\
\text { of Flood Severity } \\
\text { (Fraction of People at Risk } \\
\text { Expected to Die) }\end{array}$} \\
\hline & \multirow{2}{*}{$\begin{array}{c}\text { Maximum Depth } \\
\text { d (m) }\end{array}$} & \multirow{2}{*}{$\begin{array}{l}\text { Discharge Per Unit Width } \\
\qquad d^{*} v\left(m^{2} s^{-1}\right)\end{array}$} & \multicolumn{2}{|c|}{ Damage } & \\
\hline & & & $\begin{array}{c}\text { Garcia-Martinez and } \\
\text { Lopez (2007) }\end{array}$ & Graham (1999) & \\
\hline High & $\mathrm{d}>1.0$ & ORd $\times v>1.0$ & $\begin{array}{l}\text { People: In danger inside and } \\
\text { outside of buildings. Buildings: } \\
\text { In danger of destruction }\end{array}$ & $\begin{array}{l}\text { High severity: Complete } \\
\text { removal of buildings in } \\
\text { flood path }\end{array}$ & No cases, use 0.3 rate \\
\hline Medium & $0.2<\mathrm{d}<1.0$ & AND $0.2<\mathrm{d} \times \mathrm{v}<1.0$ & $\begin{array}{l}\text { People: In danger outside. } \\
\text { Buildings: In danger of damage } \\
\text { or destruction depending } \\
\text { on construction }\end{array}$ & $\begin{array}{l}\text { Medium severity: Homes } \\
\text { and trees mangled }\end{array}$ & 0.014 \\
\hline Low & $0.2<\mathrm{d}<1.0$ & AND d $\times \mathrm{v}<0.2$ & $\begin{array}{l}\text { People: In danger of little or no } \\
\text { damage. Buildings: In danger } \\
\text { of little damage }\end{array}$ & $\begin{array}{l}\text { Low severity: Buildings } \\
\text { not washed off } \\
\text { foundations }\end{array}$ & 0.0095 \\
\hline
\end{tabular}


For all event intensities except high, the DSO-99-06 cites historical floods where a warning was issued to the population. Therefore, for the medium and low intensity cases, we use the fatality rate for 15-60 min of warning time and a vague understanding of flood severity. This approach estimates the high fatality range and allows for conservative decision making. For the high intensity case, there is no historical case where warning was issued prior to a flood. Therefore, we use the low end of the no warning fatality rate range (0.3) to estimate fatalities from a high intensity flood with warning. The fatality rates used in this analysis are summarized in Table 1. Since, the DSO-99-06 method does not always result in integer fatalities, the fatality values are rounded to the nearest whole number.

The costs of implementing lake lowering and moraine reinforcement works were estimated from the costs of the recently completed lowering of Imja Lake by $3.4 \mathrm{~m}$. The project design included costs for lowering the lake by 3 and $5 \mathrm{~m}$ [42]. By comparing the cost estimates for the 3 and $5 \mathrm{~m}$ lake lowering, variable and fixed costs were identified. Table 2 contains the cost estimates for each lake lowering option as well as the cost type. To scale the cost of lake lowering works to the 10 and $20 \mathrm{~m}$ lowering scenarios, the cost per meter for each variable cost category was calculated using the values in Table 2. The cost per meter of lake lowering was lower for the $5 \mathrm{~m}$ project than the $3 \mathrm{~m}$ project. This difference likely is the result of decreased costs due to economies of scale.

Table 2. Cost estimates for Imja Lake lowering works. Adapted from CEPAD [42].

\begin{tabular}{|c|c|c|c|c|c|c|}
\hline \multirow{2}{*}{ Item } & \multicolumn{6}{|c|}{ Cost to Lower Lake } \\
\hline & $3 \mathrm{~m} \mathrm{( \$ )}$ & $3 \mathrm{~m}(\$ / \mathrm{m})$ & $5 \mathrm{~m} \mathrm{( \$ )}$ & $5 \mathrm{~m}(\$ / \mathrm{m})$ & $10 \mathrm{~m}(\$)$ & $20 \mathrm{~m} \mathrm{( \$ )}$ \\
\hline Variable costs & & & & & & \\
\hline Civil works & $1,101,163$ & 367,054 & $1,225,245$ & 245,049 & & \\
\hline Hydro-mechanical works & 52,742 & 17,581 & 52,742 & 10,548 & & \\
\hline Laborer logistics and insurance & 196,830 & 65,610 & 223,979 & 44,796 & & \\
\hline Insurance for works & 14,179 & 4726 & 15,420 & 3084 & & \\
\hline Water and electricity cost & 38,667 & 12,889 & 43,216 & 8643 & & \\
\hline Waste management cost & 20,334 & 6778 & 22,727 & 4545 & & \\
\hline $\begin{array}{l}\text { Subtotal variable cost } \\
\text { Fixed costs }\end{array}$ & $1,423,915$ & 474,638 & $1,583,329$ & 316,665 & $3,166,658$ & $6,333,316$ \\
\hline Health facilities & 76,282 & & 76,282 & & & \\
\hline Communication & 43,424 & & 43,424 & & & \\
\hline Heavy equipment transport & 145,762 & & 145,762 & & & \\
\hline Construction supervision & 199,757 & & 199,757 & & & \\
\hline Office, camps and warehouse & 264,024 & & 264,024 & & & \\
\hline Subtotal fixed cost & 729,249 & & 729,249 & & 729,249 & 729,249 \\
\hline Subtotal & $2,153,164$ & & $2,312,577$ & & $3,895,907$ & $7,062,565$ \\
\hline Contingencies & 107,658 & & 115,629 & & 389,591 & 706,257 \\
\hline Total & $2,260,822$ & & $2,428,206$ & & $4,285,498$ & $7,768,822$ \\
\hline
\end{tabular}

To estimate the cost to lower the lake 10 and $20 \mathrm{~m}$, the variable cost to lower the lake $5 \mathrm{~m}$ was scaled using the number of meters of lowering and added to the fixed costs. In addition, the contingency category was doubled ( $10 \%$ instead of $5 \%$ ) to account for the increased uncertainty of extrapolating cost estimates to 10 and $20 \mathrm{~m}$. It is important to note that the 10 and $20 \mathrm{~m}$ lowering costs are estimates based on smaller works at the lake. There is no guidance on the cost to lower Imja Lake by 10 and $20 \mathrm{~m}$ or how to extrapolate costs from the 3 and $5 \mathrm{~m}$ estimates, therefore the estimates calculated in this work are somewhat uncertain.

\subsection{Economic Analysis}

Using the consequence estimates of a GLOF, given different risk mitigation projects, economic analyses can be used to compare the consequences of each project to aid in decision making and to estimate the benefits or costs of a project. This approach allows a valuation of intangibles and unpriced infrastructure and a determination of which projects are efficient and have the least expected 
cost. Economic analysis was conducted using both the decision analysis (DA) and data envelopment analysis (DEA) combined with DA methods.

\subsubsection{Decision Analysis}

In the Decision Analysis (DA) method, a decision tree of the decision options, uncertainties and consequences is constructed. Figure 3 shows the decision tree for Imja Lake GLOF mitigation projects. In this tree, the maximum entropy probability distribution is used to reflect extreme uncertainty in GLOF prediction, meaning that equal probability is assigned to flooding or not flooding. This approach stems from Laplace's "Principle of Insufficient Reason," [43] which finds that in the absence of information suggesting otherwise, two events should be assigned equal probability. This reasoning is strengthened by information theory which shows that assigning two events equal probability has the greatest entropy and therefore is representative of the (minimally) available information [44]. As mentioned previously, lake lowering decreases pressure on the moraine and the probability of a breach event. Nonetheless, no information is available on how lake lowering will affect the probability of a GLOF. Therefore, we use the maximum entropy probability distribution and assign each option (flood, no flood) equal probability for all lake lowering scenarios.

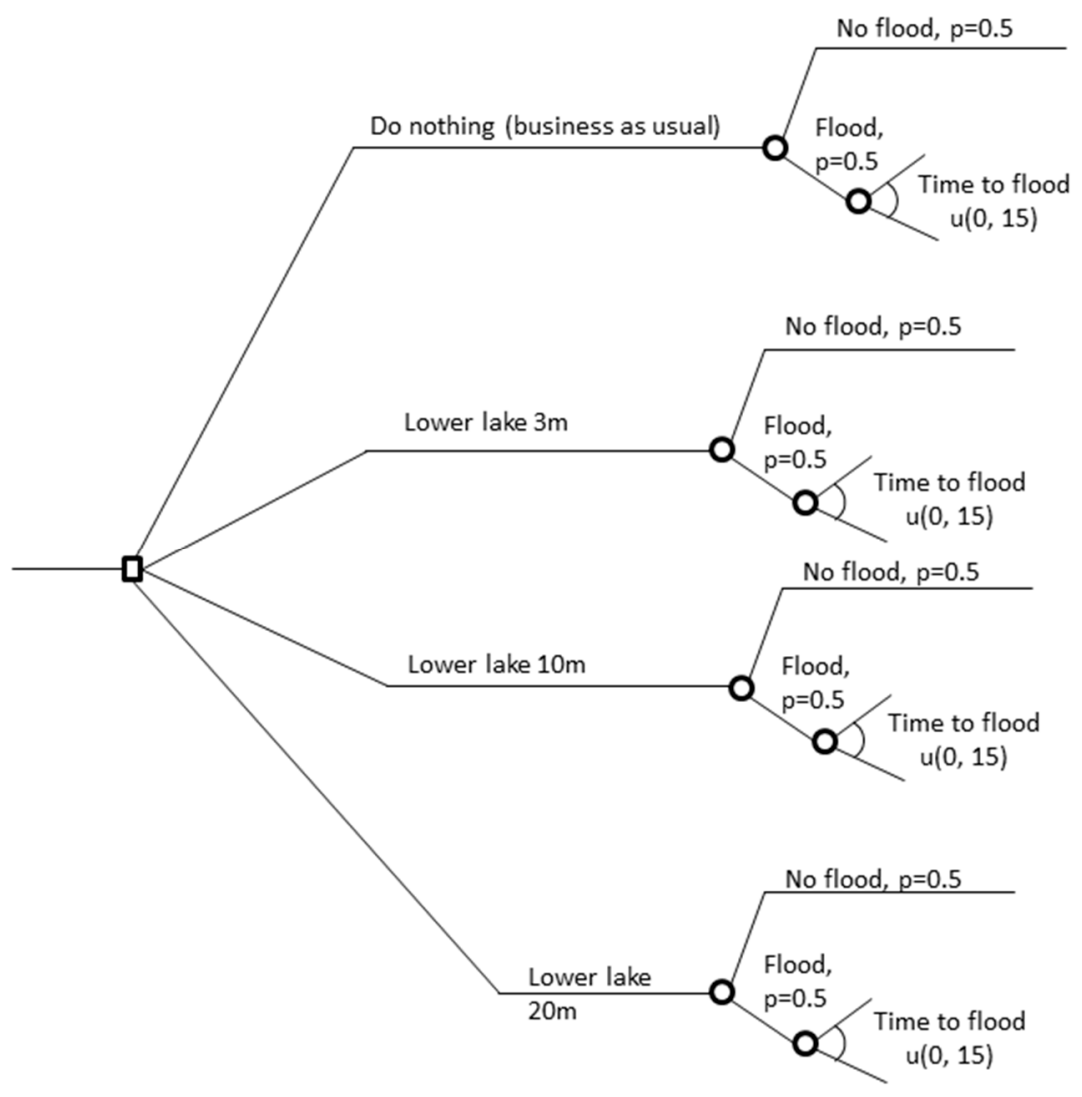

Figure 3. The decision tree for Imja GLOF risk mitigation shows potential lake lowering amounts, flood probabilities, and time to flooding.

A uniform distribution over the estimated project life (15 years in the case of the Imja Lake lowering project) is used to reflect uncertainty in the timing of a GLOF. The uniform distribution assigns equal probability to a GLOF occurring any time over the project lifetime and has the highest level of entropy while reflecting the known information. Using the uniform distribution over $\mathrm{T}$ years for the time to a GLOF gives an expected value of flood occurrence in $\mathrm{T} / 2$ years. However, a GLOF being equally likely over this time makes assumptions that diverge from the maximum entropy ideal. 
This work assumes a lifetime over which a GLOF may occur and applies the probability to a GLOF event rather than to the GLOF consequences. Both approaches require assumptions that diverge from the maximum entropy ideal. At present, insufficient information is available to define the GLOF probability and its timing. The probability distributions used here can be updated as more is learned about Imja Lake and its probability of a GLOF.

For each year that it takes for a GLOF to occur, the monetary damages were first inflated to reflect expected costs to replace damaged infrastructure in the future and then discounted to present value. An inflation rate of $9.1 \%$ was used; this is the 2016 rate of inflation for consumer prices in Nepal [45]. Then, these prices were discounted to a present value. In conducting benefit-cost analyses, the OMB (U.S. Office of Management and Budget, Washington, DC, USA) recommends that government agencies discount future costs and benefits at the same rate a typical saver would use to discount future benefits. If the policy primarily affects consumption by the individual, the recommended discount rate is 3\% (corresponding to the real return rate of long term government bonds). If the policy affects private capital, the recommended discount rate is $7 \%$ (corresponding to average return rate of capital in the US economy before taxes) [46]. The Nepal Rastra Bank (the central bank of Nepal, Kathmandu, Nepal) reports that in 2015 the rate of return for savings deposits was $2.8 \%$. The weighted average lending rate over the same time period was $9.6 \%$ [47] for an average of $6 \%$. Because it is not known how the costs from an Imja GLOF would be distributed between individuals and damage to capital, the average discount rate $(6 \%)$ is used in this analysis. It is important to note that no information is available on how Dingboche residents invest or save money. Therefore, the use of lending and savings rates is an estimate for the discount rate a Dingboche resident might use when considering future costs or benefits.

Decision analysis requires all costs and benefits to be valued in the same units, which means that a value must be assigned to intangibles (e.g., fatalities) and other damages. Because we do not have data on how Dingboche residents value fatalities, this damage category is not included in the decision analysis. The value of a statistical life (VSL) can be determined through community consultations and added to this analysis. Such work is beyond the scope of this study and is a limitation in this work. The estimated costs for different damage categories are given in Table 3.

The value of building damage can be estimated using home rebuilding estimates from the 2015 earthquake in Nepal. Several organizations and individuals requested donations from the public to rebuild homes in the areas affected by the earthquake. Although none of the requests were specifically for Dingboche, the requests provide an estimate for home construction costs in Nepal. The home cost estimates from a preliminary search ranged from $\$ 2100$ for earthquake proof, pre-fabricated homes to $\$ 14,200$ for an earthquake resistant home for an individual (the request noted that typical homes in the area cost \$5700). Other estimates were in the range $\$ 2000-\$ 5000$ (Source: Crowd funder, Kakani-One house at a time fund; Global Giving Foundation, Good Weave works; The Fuller Center for Housing; Indiegogo, Rebuild Chhulemu fund). The lowest cost (\$2100) was averaged with the highest traditional home construction cost $(\$ 5700)$ to arrive at $\$ 3850$ as the cost estimate to rebuild a damaged building. Because most of the structures at risk in the study area are uninhabited sheds or other structures, the estimate used here is considered a high estimate. Nonetheless, the cost of transporting material to the remote village of Dingboche may justify higher costs for structure construction.

Table 3. Estimated costs of damage for different categories in 2016 US dollars.

\begin{tabular}{ccc}
\hline Structures (\$/unit) & Agricultural Land $\mathbf{( \$ \mathbf { m } ^ { 2 } )}$ & Trail Length $\mathbf{( \$ / \mathbf { k m } )}$ \\
\hline$\$ 3850$ & $\$ 2.39$ & $\$ 1000$ \\
\hline
\end{tabular}

Damage to agricultural land in this area is difficult to value. The cost of replacing or rehabilitating damaged crops and lands depends on the timing of a GLOF and extent of damage. However, ICIMOD [2] valued agricultural land damaged by an Imja GLOF at $\$ 0.30 / \mathrm{m}^{2}$. Little information is 
provided on how this estimate was reached or what damages the estimate includes (monetary estimate is given for the agricultural sector). Another report from Khanal et al. [48], provides more detailed cost estimates and shows that agricultural land is valued at $\$ 1.51$ to $\$ 3.27 / \mathrm{m}^{2}$ depending on whether the land is irrigated or rain fed and the flood modeling scenario used. These cost estimates are described as real estate costs. Given that we do not have information on the type of irrigation used for at risk land in Dingboche and that the 2011 ICIMOD [2] report gives limited details for what the cost estimate includes, we averaged the two estimates from Khanal et al. [48] to obtain $\$ 2.39 / \mathrm{m}^{2}$ of agricultural land for this work.

The cost for trail damage is a rough estimate based on costs in the region. We found cost estimates for constructing hiking trails in the United States and converted them to Nepal prices using the ratio of the gross national income in both countries following the approach used to adapt value of statistical life estimates [49]. The World Bank's estimate of the Gross National Income (GNI) per capita for the US is $\$ 50,700$ [50] and income per capita in the Solu-Khumbu region of Nepal is $\$ 1841$ [51], adjusted to ensure purchasing power parity. The ratio of GNI between the two countries is 0.036 . Costs to construct hiking trails vary depending on the terrain, obstacles, and equipment and labor costs [52]. Therefore, cost estimates vary widely. Contractor estimates for trail construction in the literature range from $\$ 800$ to $\$ 1000 / \mathrm{km}$ when adjusted to Nepal prices ( $\$ 35,000$ to $\$ 48,000$ per mile unadjusted prices) $[52,53]$. We use the high end of this range, $\$ 1,000$, to allow for conservative decision making. It is important to note that actual costs for repairing trails damaged by a GLOF may differ from these estimates due to material and labor costs in Nepal, the extent of trail damage from a GLOF, and the challenges of trail construction in a remote part of the Himalayas. Therefore the cost estimate used here is intended for demonstration of the decision making methodology only and requires further refinement for decision making purposes.

The cost estimates in Table 3 were combined with the probabilities in each branch of the decision tree (Figure 3) to solve the decision tree to give the expected value of each decision. The cost of a GLOF occurrence (damages times the value of each damage category as given in Table 3 ) is multiplied by the probability of a GLOF (0.5), inflated to the expected time of GLOF occurrence, and discounted to a present value; the same procedure is followed for consequences of no GLOF (zero since there are no damages). The present value of the GLOF and no GLOF consequences are summed and the cost of any lake lowering is subtracted to give the expected value of each decision. Because a GLOF occurrence will only result in damages, the expected value of any branch's consequences is negative (they are costs). Likewise, the cost of any mitigation works has a negative value. Therefore, all decisions presented have a negative expected value.

Given that many of the damage estimates and the probabilities are uncertain, a sensitivity analysis was conducted for the variables: probability of a GLOF, time for GLOF to occur, and the discount rate. For this analysis, all other variables (other than the one analyzed) were held constant and the variable under consideration was altered by $\pm 10 \%$. The objective of the sensitivity analysis is to determine how sensitive the expected cost is to the uncertain variables.

\subsubsection{Data Envelopment Analysis}

The data envelopment analysis (DEA) methodology was first developed for use in efficiency analysis for operations research [54] and has since been applied to benefit-cost analysis $[55,56]$ to assign prices to non-market (intangible) goods in environmental cost benefit analyses. This methodology identifies the most efficient project, from an economic standpoint, if all projects competed in a perfect market. The DEA formulation of Womer et al. [56], was used here. DEA allows comparison of consequences that do not have market values or that have unknown prices (such as fatalities) and the inclusion of conflicting perspectives on what is a cost or benefit [56]. DEA does so by reversing the question posed in a traditional benefit-cost analysis and asking what values of costs and 
benefits (prices) are required to make a given project economically efficient [55]. The DEA method is summarized as

$$
\underset{p}{\operatorname{Max}} p w^{*}
$$

subject to

$$
\begin{gathered}
w p \leq 0 \\
p_{1}=1 \\
p \geq 0
\end{gathered}
$$

In Equation (1), the benefits and costs of the proposed projects (of which there are $m$ ) are aggregated in the attribute matrix $(w, m \times n)$. The sum of the costs and benefits for a given project $\left(w^{*}\right.$, an array, $\left.n \times 1\right)$ multiplied by the prices ( $p$, a vector of decision variables, $\left.1 \times n\right)$ is maximized given the constraint that no project produce a "profit" (Equation (1b)). In Equation (1c), $p^{i}$ (scalar) is used as a numeraire (normalizing weight) to avoid the trivial solution that all entries in $p$ equal zero. If the price for a given effect (benefit or cost) is positive, then it is counted as a benefit; a negative price indicates a cost. The analysis is conducted for each project one at a time to obtain an array of prices that make the project being analyzed efficient.

The DEA methodology works by balancing benefits and costs given market constraints. The methodology identifies the efficient benefit production frontier given the sample of projects and identifies which projects are on the frontier [55]. In the case of a GLOF from Imja Lake, the benefit provided by mitigation projects is a decrease in damages compared to the BAU scenario at the cost of the lake lowering works. Therefore, for the DEA, damages relative to the BAU scenario are used in the DEA.

The outcome of the DEA model is a matrix of prices $(m \times n)$ for each consequence category and project and the value of each project. Net benefits (given in dollar units) are used as the numeraire and so its price is set to +1 since it is a benefit. Additionally, by assigning net benefits a price of one, all other prices are in units of dollars. The maximum value possible for a project is zero given the constraints of the DEA model (Equation (1)). Projects that do not maximize the benefit-cost Equation (1a) under the problem constraints are not on the efficient frontier in the project "market". The price vectors give important information about how each alternative "scores" for each consequence. A low price for a given consequence indicates that it contributes little to making the project efficient.

The DEA and decision analysis methodologies were combined by using the expected damage values in the DEA methodology. To do this, the relative damage values for net benefits were adjusted using the probability of a GLOF and the time to a flood with the given inflation and discount rates. Non-monetary damages (intangibles and those with uncertain cost estimates: fatalities, agricultural land, trail length) are adjusted using the probability of a GLOF but not inflated or discounted. The non-monetary damages are the ones with the least information: agricultural land damage is based on a single cost estimate with limited transparency, trail length is roughly estimated from flood intensity areas along the trail and priced using adjusted US trail construction costs, and fatalities are not priced due to a lack of data. We use the DEA method to estimate how the non-monetary damage categories should be valued to make a given project efficient. Building costs, on the other hand, are based on multiple estimates of real home building costs in Nepal. Therefore, only monetary building damage costs are inflated and discounted, since the damage quantity of unvalued damage categories does not change with the timing of the GLOF event. We use high season fatality rates in this analysis to provide a worst case scenario for conservative decision making.

The DEA results show the projects that are efficient under a range of prices. The maximum value of this range is determined by shadow prices for each damage category. Projects are efficient if the shadow price for any consequence category is less than that of another project. The shadow price is calculated by dividing the absolute value of net benefits (monetary cost of each project) by the benefits provided by each project (avoided damages in the $w^{*}$ vector from Equation (1a)) for 
each damage category (fatalities, agricultural land, and trails). In the case that a given project has a minimum shadow price, it is possible to price that damage category (at the shadow price) such that the project attains a value of zero and other projects have a value less than zero (fulfills the constraints in Equation (1b)). The minimum shadow price for each damage category establishes an efficient frontier and bounds the price for each damage category in accordance with the DEA constraints. These constraining prices are the upper bound (lower bound is zero) for the range of prices that result in at least one project being efficient while fulfilling the DEA constraints. The shadow price analysis also lets us identify projects that can attain efficiency if damage categories are priced correctly. Any project with a minimum shadow price for one of the damage categories is efficient since pricing the damage category at the minimum shadow price results in a value of zero (condition for efficiency) for that project and fulfills all DEA constraints.

\section{Results and Discussion}

\subsection{Damage Estimates}

GLOF inundation scenarios were previously calculated and reported in Somos-Valenzuela et al. [18] using HEC-RAS [57] to simulate moraine failure and FLO-2D [58] to simulate water and debris flow in the valley downstream. This study relies on published flooding information. Somos-Valenzuela et al. [18] is the only report to give details of flood characteristics downstream of Imja Lake with and without lake lowering. Modeling was not conducted further downstream because digital elevation models of sufficient resolution were not available further downstream at the time the study was conducted [18]. Therefore, the results of this analysis are incomplete for decision making purposes as the full extent of the damage from an Imja GLOF has not been quantified. Significant damages downstream of the modeled area may change the lowest cost decision arrived at here. In particular, FLO-2D was used to calculate the flood characteristics downstream as a function of time (see [18] for modeling details). Somos-Valenzuela estimate that the lake contains $61.7 \pm 3.7$ million $\mathrm{m}^{3}$ of water initially (this is without lowering works) of which $34.1 \pm 1.08$ million $\mathrm{m}^{3}$ would drain in the event of a full moraine breach ( $35 \mathrm{~m}$ vertical breach of the moraine). Lowering the lake by 3, 10 and $20 \mathrm{~m}$ would result in lake volumes of $29.5,22.4$, and 12.5 million $\mathrm{m}^{3}$, respectively, exiting the lake in the event of a full moraine breach [18]. Results from the modeling (maximum depth and discharge per unit width rasters) were used for this analysis. The results simulate approximately $\sim 7 \mathrm{~km}$ of the watershed downstream from the outlet of Imja Lake to the first major downstream village of Dingboche. In the Imja Lake GLOF modeling of Somos-Valenzuela [18] a $5 \mathrm{~m} \times 5 \mathrm{~m}$ resolution DEM extending from the lake to just below Dingboche derived using the method of Lamsal et al. [59] was used. Data were not available to extend the $5 \mathrm{~m} \times 5 \mathrm{~m}$ DEM coverage downstream of Dingboche, so a lower resolution DEM was used by Somos-Valenzuela et al. [18] for the region downstream of Dingboche [18]. In the upper portion, Imja Lake to Dingboche, the high-quality terrain information is adequate for the analysis reported here, but not for the section below Dingboche. The FLO-2D outputs were converted to flood intensity regions using the categories given in Table 1 . This study assumes that failure of the terminal moraine of Imja Lake will result in a $35 \mathrm{~m}$ vertical breach. This level of moraine erosion as well as the risk for moraine failure is disputed in the literature (as noted previously [24,30-32]) and by recent unpublished research. Nonetheless, we use these results to demonstrate the decision-making methodology because Somos-Valenzuela et al. [18] is the only study to evaluate the change in flood characteristics with and without lake lowering works.

Previous attempts at predicting outflow from potential failures of the Imja Lake moraine have assumed, from a worst-case approach, that total collapse of the moraine is possible [2,18]. Although the history of GLOFs presents cases of large-scale breaches in diverse glacial settings, whether a total collapse at Imja Lake is physically possible remains an unanswered question. To drain most of its impounded water, Imja Lake requires a breach $91 \mathrm{~m}$ wide and $35 \mathrm{~m}$ deep, forming a continuous outlet at the front moraine [18]. Complete moraine failure and subsequent outburst floods have occurred 
at Queen Bess Lake [60], Lake Ventisquero Negro [61], and Tam Pokhari Lake [62]. However, the morphology of Imja Lake possesses a set of unique characteristics that could inhibit a large breach of its present moraine: (1) the moraine dam is large; (2) is not showing signs of rapid degradation even though it is ice-cored; (3) the irregular lake bed near the moraine is an obstacle to flow; (4) it has a well-defined and curved outlet channel that has recently been reinforced; and (5) the lake has shown some stability in the area near the moraine over the last 10 years [25].

It is possible that internal self-destructive erosion or overtopping waves generated from future avalanche events would not cause sufficient erosion to initiate a breach of the moraine and release the lake water, thus rendering a full collapse of the moraine extremely unlikely. However, there are no definitive studies that have analyzed this situation under the present or future lake conditions. The authors consider this scenario nearly impossible given the current understanding of the moraine conditions and proximity to avalanche runout paths from the surrounding high mountains [23]. The decision of which scenario to eventually include in hazard identification or inundation mapping is not just a scientific question, but also a political one. The results of the full breaching scenario are used since they represent the worst-case scenario which should be communicated to decision makers and stakeholders. For the sake of providing complete information, the probable maximum inundation [13] as a result of a full breach of the damming moraine at Imja Lake was used, assuming this event is the worst possible scenario that could conceivably occur. This probable maximum inundation was estimated by modeling the event of a full collapse of the moraine following an internal self-destructive piping event that erodes the moraine to the extent that the release of the lake water can maintain the erosion and create a full breach of the moraine [18].

As described previously, a building inventory was developed and verified during a field visit to estimate damages from a GLOF. Figure 4 shows a summary of the structures in Dingboche inventoried for the infrastructure inventory and Table 4 contains a sample of the information gathered about them. Figure 4 shows the resulting flood intensity regions overlapped with an image of the village of Dingboche (high in red and low in yellow) for BAU (no lowering), 3, 10, and $20 \mathrm{~m}$ lake lowering.

Table 4. Sample of infrastructure inventory data collected during field inventory in Dingboche.

\begin{tabular}{cccc}
\hline$\#$ & Low Season Inhabitants & High Season Inhabitants & Building Type \\
\hline 0 & 3 & 3 & Tea house (1.5 years old) \\
1 & 0 & 0 & Storage \\
2 & 0 & 0 & Storage \\
3 & 0 & 0 & Storage \\
4 & 0 & 0 & Storage \\
5 & 2 & 2 & Snooker tea house \\
6 & 0 & 0 & Storage \\
7 & 0 & 0 & Storage \\
8 & 0 & 0 & Storage \\
9 & 2 & 2 & House \\
10 & 20 & 20 & Lodge \\
11 & 0 & 0 & Rock pile \\
12 & 2 & 46 & Resort and auxiliary rooms \\
13 & 0 & 0 & Resort and auxiliary rooms \\
14 & 0 & 0 & Storage \\
15 & 0 & 0 & Camping kitchen connected to lodge \\
16 & 0 & 0 & Trash \\
17 & 0 & 0 & Storage \\
18 & 2 & 14 & House for porters \\
19 & 0 & 0 & Storage \\
20 & 0 & 3 & House with seasonally occupied tent \\
\hline
\end{tabular}




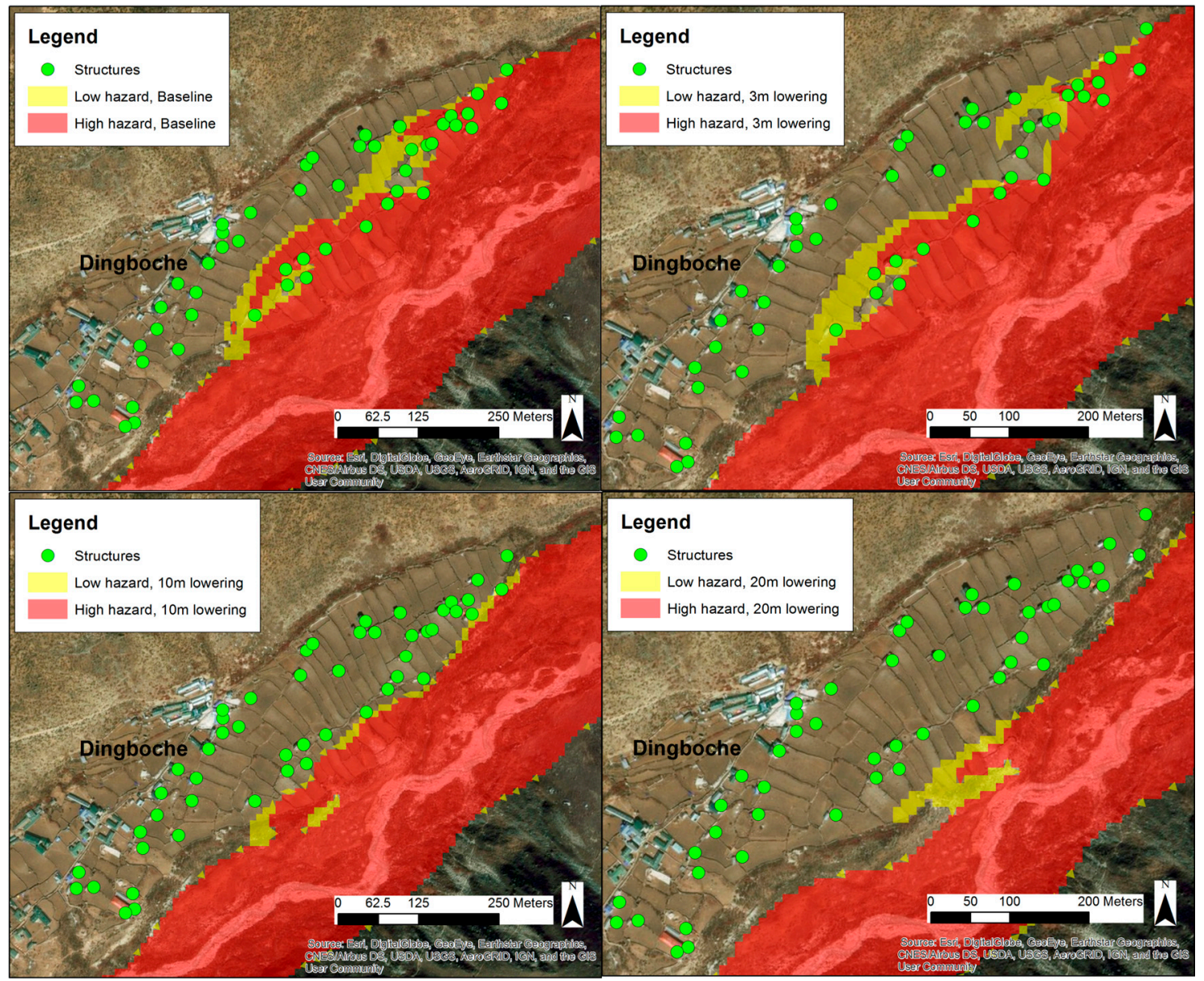

Figure 4. Infrastructure and population inventory in Dingboche identified using satellite imagery and verified by field inventory. Flood intensity regions (high in red and low in yellow) in Dingboche. Clockwise from top left, the images show flood severity for no lowering (business as usual (BAU)), $3 \mathrm{~m}$ lowering, $10 \mathrm{~m}$ lowering, and $20 \mathrm{~m}$ lowering.

Information from the field inventory on number of inhabitants was combined with the fatality rate ranges in Table 1 and flood severity classifications in Figure 4 to estimate fatalities from a potential GLOF (Table 5). Combining the field inventory with flood modeling results and fatality estimates, the consequences of a potential GLOF with and without adaptation measures were estimated (Table 5).

Table 5. Damage estimates for people and infrastructure at Dingboche under different Imja Lake lowering scenarios.

\begin{tabular}{ccccccc}
\hline $\begin{array}{c}\text { Lake } \\
\text { Lowering }\end{array}$ & $\begin{array}{c}\text { Fatalities, High } \\
\text { Season (People) }\end{array}$ & $\begin{array}{c}\text { Fatalities, } \\
\text { Low Season } \\
\text { (People) }\end{array}$ & $\begin{array}{c}\text { Buildings } \\
\text { Damaged } \\
\text { (Buildings) }\end{array}$ & $\begin{array}{c}\text { Ag. Land } \\
\text { Damaged } \\
\left.\mathbf{( m}^{\mathbf{2}}\right)\end{array}$ & $\begin{array}{c}\text { Trail Length } \\
\text { Damaged } \\
\mathbf{( k m )}\end{array}$ & $\begin{array}{c}\text { Cost of Lake } \\
\text { Lowering } \\
\mathbf{( \$ )}\end{array}$ \\
\hline BAU & 3 & 1 & 20 & 93,650 & 7.97 & 0 \\
$3 \mathrm{~m}$ & 2 & 0 & 14 & 86,262 & 7.85 & $2,260,822$ \\
$10 \mathrm{~m}$ & 0 & 0 & 4 & 40,226 & 7.45 & $4,285,496$ \\
$20 \mathrm{~m}$ & 0 & 0 & 1 & 10,686 & 4.64 & $7,768,820$ \\
\hline
\end{tabular}




\subsection{Economic Analysis}

\subsubsection{Decision Analysis}

The expected total costs (benefits-project cost) for each project using the baseline parameter values (probability of flood $=0.50$, time to GLOF $=15$ years, discount rate $=6 \%$ ) are shown in Table 6 . All expected total cost values in Table 6 are negative because a GLOF occurrence will only incur costs (damage to infrastructure and individuals). No GLOF will result in zero costs except in the case where a lake lowering project is implemented. The lowest expected cost project is the most favorable decision, from an economic point of view, since costs are minimized. The results indicate that the no lowering project (BAU) has the lowest expected total cost of any of the projects proposed. Although the lake lowering scenarios would decrease damages significantly (particularly in the fatalities, agricultural land and homes categories), the future cost for damages (not including fatalities as data does not exist to value them) does not justify the present cost of lake lowering projects.

Table 6. Expected total costs of potential lake lowering projects relative to the 0 -m lowering case using baseline parameter values (probability of flood $=0.50$, time to GLOF $=15$ years, inflation rate $=9.1 \%$, discount rate $=6 \%$ ).

\begin{tabular}{cccccc}
\hline \multirow{2}{*}{ Lake Lowering } & \multirow{2}{*}{ Cost } & \multicolumn{2}{c}{ Damages (Cost of a GLOF) } & \multirow{2}{*}{ Expected Total Costs } \\
& $\mathbf{( \$ )}$ & $\mathbf{B u i l d i n g s}$ & $\mathbf{A g . ~ L a n d}$ & Trails & $\mathbf{( \$ )}$ \\
& 0 & 77,000 & 223,824 & 7970 & $-\$ 191,660$ \\
BAU & $2,260,822$ & 53,900 & 206,166 & 7850 & $-\$ 2,427,109$ \\
$3 \mathrm{~m}$ & $4,285,496$ & 15,400 & 96,140 & 7450 & $-\$ 4,359,350$ \\
$10 \mathrm{~m}$ & $7,768,820$ & 3850 & 25,540 & 4640 & $-\$ 7,789,941$ \\
\hline
\end{tabular}

A sensitivity analysis was conducted to determine the effect that variations in the model parameters (probability of flood, time to GLOF, and discount rate) have on the decision. The results in Table 7 show that relatively small deviations in the parameters do not have a large effect on the expected total cost, but the results are sensitive to larger parameter variations. The BAU alternative shows the greatest sensitivity to all parameters, mostly because of the large future costs of a GLOF due to the high inflation rate (this means that future prices are much greater than present prices even after discounting). Nonetheless, none of the variations resulted in a change in the lowest expected cost decision.

Table 7. Sensitivity analysis results showing the change in expected total costs due to changes in the parameter values.

\begin{tabular}{|c|c|c|c|c|c|c|c|c|c|c|c|c|c|}
\hline \multirow[t]{2}{*}{ Parameter } & \multirow[t]{2}{*}{ Baseline } & \multicolumn{4}{|c|}{$\begin{array}{l}\text { Parameter Set } 1 \\
\text { GLOF Probability }\end{array}$} & \multicolumn{4}{|c|}{$\begin{array}{c}\text { Parameter Set } 2 \text { Time } \\
\text { to GLOF }\end{array}$} & \multicolumn{4}{|c|}{ Parameter Set 3 Discount Rate } \\
\hline & & Low & $-10 \%$ & $+10 \%$ & $\mathbf{H i}$ & Low & $-10 \%$ & $+10 \%$ & $\mathrm{Hi}$ & Low & $-10 \%$ & $+10 \%$ & $\mathbf{H i}$ \\
\hline Expected time to GLOF & 7.5 & & & & & 3.75 & 6.75 & 8.25 & 15 & & & & \\
\hline Discount rate & 0.06 & & & & & & & & & 0.025 & 0.054 & 0.066 & 0.12 \\
\hline Discount factor & 0.646 & & & & & 0.804 & 0.675 & 0.618 & 0.417 & 0.831 & 0.674 & 0.619 & 0.427 \\
\hline BAU & 0 & -50.0 & -10.0 & 10.0 & 50.0 & -10.3 & -2.14 & 2.19 & 24.13 & 28.6 & 4.35 & -4.14 & -33.83 \\
\hline $3 \mathrm{~m}$ & 0 & -3.4 & -0.69 & 0.69 & 3.43 & -0.70 & -0.15 & 0.15 & 1.65 & 1.96 & 0.30 & -0.28 & -2.32 \\
\hline $10 \mathrm{~m}$ & 0 & -0.85 & -0.17 & 0.17 & 0.85 & -0.17 & -0.04 & 0.04 & 0.41 & 0.49 & 0.07 & -0.07 & -0.57 \\
\hline $20 \mathrm{~m}$ & 0 & -0.14 & -0.03 & 0.03 & 0.14 & -0.03 & -0.01 & 0.01 & 0.07 & 0.08 & 0.01 & -0.01 & -0.09 \\
\hline
\end{tabular}

As more information is learned about the probability of a flood and likely time to occurrence, the decision tree variables in Figure 3 can be updated. New or updated probability distributions can then be used to solve the decision tree and obtain a better estimate of the expected cost of each decision. 


\subsubsection{Data Envelopment Analysis}

The expected values from the decision analysis method were used in the DEA model. Values used in this analysis are summarized in Table 8 . The cost of lake lowering would be paid in the present and is not uncertain, therefore the cost of lake lowering remains unchanged from the values given in Table 2 (this value is subtracted from building undamaged costs of Table 8 to give the monetary valued damages in Table 8). Building damage is the only category in Table 8 that is inflated and then discounted as it is given in monetary units and because these damages will occur in the future. The non-monetary avoided damages (fatalities, ag. land, and trails), on the other hand, are not expected to change in the future because they quantify physical damage, which is not subject to discounting or inflation. Avoided damages were calculated relative to the BAU case (all columns labeled 'undamaged' or avoided in Table 8). The monetary valued damages are used as the numeraire in the DEA. Monetary valued damages and non-monetary benefits (fatalities avoided, ag. land undamaged, trails undamaged) in Table 8 were used in the DEA model.

Table 8. Expected damage values relative to the BAU case with discounting over 7.5 years (event occurrence uniformly distributed over 15 years).

\begin{tabular}{ccccccc}
\hline $\begin{array}{c}\text { Lake } \\
\text { Lowering }\end{array}$ & $\begin{array}{c}\text { Monetary } \\
\text { Valued Damages }\end{array}$ & $\begin{array}{c}\text { Fatalities } \\
\text { Avoided } \\
(\#)\end{array}$ & $\begin{array}{c}\text { Ag. Land } \\
\text { Undamaged } \\
\left(\mathbf{m}^{\mathbf{2}} \mathbf{)}\right.\end{array}$ & $\begin{array}{c}\text { Trails } \\
\text { Undamaged } \\
\mathbf{( k m )}\end{array}$ & $\begin{array}{c}\text { Buildings } \\
\text { Undamaged } \\
\mathbf{( \$ )}\end{array}$ & $\begin{array}{c}\text { Lake Lowering } \\
\text { Cost } \\
\mathbf{( \$ )}\end{array}$ \\
\hline $3 \mathrm{~m}$ & $-\$ 2,246,484$ & 1 & 2386 & 0.06 & 14,338 & $2,260,822$ \\
$10 \mathrm{~m}$ & $-\$ 4,247,263$ & 2 & 17,255 & 0.26 & 38,233 & $4,285,496$ \\
$20 \mathrm{~m}$ & $-\$ 7,723,417$ & 2 & 26,796 & 1.67 & 45,402 & $7,768,820$ \\
\hline
\end{tabular}

Using the DEA method, lowering the lake 10 and $20 \mathrm{~m}$ were found to be efficient projects. Using the shadow price analysis, the constraining prices summarized in Table 9 were calculated. These are the maximum price for each damage category (the minimum price is zero) that will fulfill the DEA constraints. This shows that the damage categories must be priced much greater than the estimates provided in Table 3 for the 10 or $20 \mathrm{~m}$ lowering project to achieve efficiency. One of the efficient lake lowering projects could also achieve efficiency (value of zero) if all damage categories are priced high enough, however doing so would require prices much greater than the estimates in Table 3.

Table 9. Constraining prices for expected avoided damages under which lake lowering (10 or $20 \mathrm{~m})$ is efficient.

\begin{tabular}{ccc}
\hline Fatalities (\$Statistical Life) & Ag. Land $\mathbf{( \$ \mathbf { m } ^ { 2 } )}$ & Trail Length $\mathbf{( \$ / \mathbf { k m } )}$ \\
\hline $1,415,754$ & 159 & $4,638,689$ \\
\hline
\end{tabular}

As discussed by Somos-Valenzuela et al. [13], the general lack of field data regarding actual GLOF events leads to many unknowns about the processes, particularly those related to avalanches, lake dynamics and moraine erosion. There is very little information on avalanche characteristics, magnitude of avalanche-generated waves, or erosive capabilities of overtopping waves on which to base validation of these simulated processes. In the work reported here, avalanches are not considered to be a potential GLOF trigger since the current avalanche runouts do not reach the lake [23]. Considering the relative impacts of the GLOF process components: (1) avalanche size (which is not simulated in the Imja Lake case considered here) may have the most significant impact on downstream flood hazard, followed by; (2) modeling avalanche-generated waves; (3) erosion of the damming moraine; and (4) modeling downstream inundation. Although results from previous work [13] on a Peruvian glacial lake indicate that complete moraine failure can be extremely unlikely, the possibility of a catastrophic breach cannot be categorically excluded based on existing evidence, and breaching will 
significantly increase downstream inundated area. Modeling downstream inundation is sensitive to (1) sediment concentration, (2) flow rheology, and (3) roughness.

In this analysis, the damages in Dingboche from an Imja GLOF including fatalities and damages to infrastructure were estimated using readily available data in the literature. In addition, the cost for the lake lowering works proposed was estimated. This information allowed for the comparison of the proposed projects based on their costs and potential damages from a GLOF. The analysis shows that the damage from a GLOF from Imja Lake in Dingboche is not sufficient to justify the cost of lowering the lake under the price estimates used here. Nonetheless, this option could not be analyzed using DEA. Therefore, if the decision tree values are considered valid by stakeholders, then not lowering Imja Lake and relying on the installed early warning system is the best decision from an economic standpoint. This is not to say that investment in decreasing damages is not economically justified, only that the values found in the literature for the damages considered here do not balance the cost of lake lowering projects. However, there are several variables unaccounted for in this analysis that could change this conclusion. Higher costs for the damages in Dingboche, high costs for damages not included in this analysis (including damages downstream of Dingboche) or different decision tree variables from those used here could change the lowest cost decision and would require that the efficiency of the proposed projects be reassessed.

\section{Conclusions}

The DA methodology allowed for the comparison of proposed projects considering uncertainty in the timing and likelihood of a GLOF. However, the DA methodology required that the cost of unvalued infrastructure be estimated for Dingboche. The DA found that the lowest cost decision was the BAU scenario and that the decision is sensitive to small changes in the decision tree variables.

The DA and DEA methodologies were combined by using expected values in the DEA. This approach showed that lowering the lake 10 or $20 \mathrm{~m}$ are efficient decisions when uncertainty in the timing and occurrence of a GLOF is considered. This result is meaningful because it does not require that the value of intangibles or unvalued infrastructure be estimated. However, the BAU scenario could not be assessed in this analysis. Because DEA as applied here cannot compare the BAU decision to the proposed projects, this result must be considered in the context of the DA result.

Although the DEA methodology was successfully utilized to identify efficient projects for Imja Lake as well as the range of prices that fulfill the DEA constraints, the methodology is not well suited to the problem analyzed here. Because of the lack of benefits other than deferred damages from any of the projects, the BAU decision could not be assessed using the DEA methodology, even though it was found to be the lowest cost project in the DA. Nonetheless, the framework of the DEA methodology proved useful for framing the decision (a competitive marketplace of projects) and for calculating a range of prices under which decisions are efficient.

Future work should include modeling the damage from an Imja GLOF downstream of Dingboche, community consultations to refine damage cost estimates, and using new information to update the decision tree variables. Significant damages downstream may change the lowest cost decision arrived at here. Likewise, community valuation of damaged infrastructure as well as their input on what damages a GLOF may incur should be included to obtain a complete estimate of the cost of a GLOF event. The addition of these damages and costing information may change the results arrived at here. In addition, any new information on the likelihood and timing of a GLOF should be used to update the probability distributions in the decision tree (Figure 3). Updated damage, economic data (discount and inflation rates), and probability distributions should be used in the decision-making methodology to refine the estimate of the best decision from an economic standpoint for Imja Lake. This information should be verified with Dingboche residents to ensure it reflects actual costs in the region.

Most importantly, however, more information should be included regarding the damages from a potential GLOF to the inhabitants of Dingboche and communities downstream. This work relied on readily available data and quantitative information on what infrastructure is at risk from a GLOF. 
Other intangible and indirect damages (health and well-being over time, economic opportunities after a GLOF event, and damage to the community culture) should be understood and can be included in the decision-making methodology. A complete analysis of the costs and benefits of GLOF mitigation works must include community input to understand how local stakeholders value at risk infrastructure and the consequences that a GLOF would have on stakeholders. Ultimately, though, the decision of what project to pursue is made considering social values and preferences. Although economic analyses such as those presented here can inform the process, the decision will likely not be a purely economic one.

Acknowledgments: The authors acknowledge the support of the NSF-CNH program (award No. 1516912) for the support of Amanda Cuellar and Daene McKinney. The authors greatly appreciate the assistance of Alton Byers and David Rounce in the Dingboche inventory.

Author Contributions: Cuellar and McKinney conceived and designed the experiments; Cuellar performed the modeling and analyzed the results; Cuellar and McKinney wrote the paper.

Conflicts of Interest: The authors declare no conflict of interest.

\section{References}

1. Roe, G.H.; Baker, M.B.; Herla, F. Centennial glacier retreat as categorical evidence of regional climate change. Nat. Geosci. 2016, 10, 95-99. [CrossRef]

2. ICIMOD-International Centre for Integrated Mountain Development. Glacial Lakes and Glacial Lake Outburst Floods in Nepal; International Centre for Integrated Mountain Development (ICIMOD): Kathmandu, Nepal, 2011.

3. Gardelle, J.; Arnaud, Y.; Berthier, E. Contrasted evolution of glacial lakes along the Hindu Kush Himalaya mountain range between 1990 and 2009. Glob. Planet. Chang. 2011, 75, 47-55. [CrossRef]

4. Carrivick, J.L.; Tweed, F.S. Proglacial lakes: Character, behavior and geological importance. Quat. Sci. Rev. 2013, 78, 34-52. [CrossRef]

5. Carey, M.; Huggel, C.; Bury, J.; Portocarrero, C.; Haeberli, W. An integrated socio-environmental framework for glacier hazard management and climate change adaptation: Lessons from Lake 513, Cordillera Blanca, Peru. Clim. Chang. 2011, 112, 733-767. [CrossRef]

6. Rabatel, A.; Francou, B.; Soruco, A.; Gomez, J.; Cáceres, B.; Ceballos, J.L.; Basantes, R.; Vuille, M.; Sicart, J.-E.; Huggel, C.; et al. Current state of glaciers in the tropical Andes: A multi-century perspective on glacier evolution and climate change. Cryosphere 2013, 7, 81-102. [CrossRef]

7. Portocarrero, C. The Glacial Lake Handbook: Reducing Risk from Dangerous Glacial Lakes in the Cordillera Blanca, Peru; United States Agency for International Development: Washington, DC, USA, 2014.

8. Eriksson, M.; Juanchu, X.; Shrestha, A.B.; Vaidya, R.A.; Nepal, S. The Changing Himalayas-Impact of Climate Change on Water Resources and Livelihoods in the Greater Himalayas, Perspectives on Water and Climate Change Adaptation, ICIMOD-International Centre for Integrated Mountain Development: Glacial Lakes and Glacial Lake Outburst Floods in Nepal; International Centre for Integrated Mountain Development (ICIMOD): Kathmandu, Nepal, 2009.

9. Vuichard, D.; Zimmermann, M. The 1985 Catastrophic Drainage of a Moraine-Dammed Lake, Khumbu Himal, Nepal: Cause and Consequences. Mt. Res. Dev. 1987, 7, 91-110. [CrossRef]

10. Watanbe, T.; Rothacher, D. The 1994 Lugge Tsho Glacial Lake Outburst Flood, Bhutan Himalaya. Mt. Res. Dev. 1996, 16, 77-81. [CrossRef]

11. Worni, R.; Huggel, C.; Stoffel, M. Glacial lakes in the Indian Himalayas-from an area-wide glacial lake inventory to on-site and modeling based risk assessment of critical glacial lakes. Sci. Total Environ. 2012, 468-469, 71-84. [CrossRef] [PubMed]

12. Westoby, M.J.; Glasser, N.F.; Brasington, J.; Hambrey, M.J.; Quincey, D.J.; Reynolds, J.M. Modelling outburst floods from moraine-dammed glacial lakes. Earth-Sci. Rev. 2014, 134, 137-159. [CrossRef]

13. Somos-Valenzuela, M.A.; Chisolm, R.E.; Rivas, D.S.; Portocarrero, C.; McKinney, D.C. Modeling glacial lake outburst flood process chain: The case of Lake Palcacocha and Huaraz, Peru. Hydrol. Earth Syst. Sci. 2016, 20, 2519-2543. [CrossRef] 
14. Worni, R.; Huggel, C.; Clague, J.J.; Schaub, Y.; Stoffel, M. Coupling glacial lake impact, dam breach, and flood processes: A modeling perspective. Geomorphology 2014, 224, 161-176. [CrossRef]

15. Watson, C.S.; Carrivick, J.; Quincey, D. An improved method to represent DEM uncertainty in glacial lake outburst flood propagation using stochastic simulations. J. Hydrol. 2015, 529, 1373-1389. [CrossRef]

16. Westoby, M.J.; Glasser, N.F.; Hambrey, M.J.; Brasington, J.; Reynolds, J.M.; Hassan, M.A.A.M. Reconstructing historic Glacial Lake Outburst Floods through numerical modelling and geomorphological assessment: Extreme events in the Himalaya. Earth Surf. Process. Landf. 2014, 39, 1675-1692. [CrossRef]

17. Nie, Y.; Sheng, Y.; Liu, Q.; Liu, L.; Liu, S.; Zhang, Y.; Song, C. A regional-scale assessment of Himalayan glacial lake changes using satellite observations from 1990 to 2015. Remote Sens. Environ. 2017, 189, 1-13. [CrossRef]

18. Somos-Valenzuela, M.A.; McKinney, D.C.; Byers, A.C.; Rounce, D.R.; Portocarrero, C.; Lamsal, D. Assessing downstream flood impacts due to a potential GLOF from Imja Tsho in Nepal. Hydrol. Earth Syst. Sci. 2015, 19, 1401-1412. [CrossRef]

19. Rana, B.; Shrestha, A.B.; Reynolds, J.M.; Aryal, R.; Pokhrel, A.P.; Budathoki, K.P. Hazard Assessment of the Tsho Rolpa Glacier Lake and Ongoing Remediation Measures. J. Nepal Geol. Soc. 2000, 22, 563-570.

20. UNDP-United Nations Development Programme: Community Based Glacier Lake Outburst and Flood Risk Reduction in Nepal. Project Document, UNDP Environmental Finance Services, Kathmandu, Nepal. 2012. Available online: http:/ / www.adaptation-undp.org/resources/prodocs/nepal-ldcf-prodoc-15-november2012 (accessed on 14 July 2017).

21. Khadka, N.S. Nepal Drains Dangerous Everest Lake BBC World Service. 31 October 2016. Available online: http:/ / www.bbc.com/news/world-asia-37797559 (accessed on 14 April 2017).

22. Khanal, N.R.; Mool, P.K.; Bhakta, S.; Rasul, G.; Ghimire, P.K.; Shrestha, R.B.; Joshi, S.P. A comprehensive approach and methods for glacial lake outburst flood risk assessment, with examples from Nepal and the transboundary area. Water Resour. Dev. 2015, 31, 219-237. [CrossRef]

23. Rounce, D.R.; McKinney, D.C.; Lala, J.M.; Byers, A.C.; Watson, C.S. A New Remote Hazard and Risk Assessment Framework for Glacial Lakes in the Nepal Himalaya. Hydrol. Earth Syst. Sci. 2016, 20, 3455-3475. [CrossRef]

24. Watanabe, T.; Ives, J.D.; Hammond, J.E. Rapid Growth of a Glacial Lake in Khumbu Himal, Himalaya: Prospects for a Catastrophic Flood. Mt. Res. Dev. 1994, 14, 329-340. [CrossRef]

25. Somos-Valenzuela, M.A.; McKinney, D.C.; Rounce, D.R.; Byers, A.C. Changes in Imja Tsho in the Mt. Everest region of Nepal. Cryosphere 2014, 8, 1661-1671. [CrossRef]

26. Thakuri, S.; Salerno, F.; Bolch, T.; Guyennon, N.; Tartari, G. Factors controlling the accelerated expansion of Imja Lake, Mount Everest region, Nepal. Ann. Glaciol. 2016, 57, 245-257. [CrossRef]

27. Kattelmann, R. Glacial Lake Outburst Floods in the Nepal Himalaya: A Manageable Hazard? Nat. Hazards 2003, 28, 145-154. [CrossRef]

28. Ives, J.D.; Shrestha, R.B.; Mool, P.K. Formation of Glacial Lakes in the Hindu Kush-Himalayas and GLOF Risk Assessment; International Centre for Integrated Mountain Development (ICIMOD): Kathmandu, Nepal, 2010.

29. Fujita, K.; Sakai, A.; Nuimura, T.; Yamaguchi, S.; Sharma, R.R. Recent changes in Imja Glacial Lake and its damming moraine in the Nepal Himalaya revealed by in situ surveys and multi-temporal ASTER imagery. Environ. Res. Lett. 2009, 4. [CrossRef]

30. Watanabe, T.; Lamsal, D.; Ives, J.D. Evaluating the growth characteristics of a glacial lake and its degree of danger of outburst flooding: Imja Glacier, Khumbu Himal, Nepal. Norsk. Geografisk. Tidsskrift 2009, 63, 255-267. [CrossRef]

31. Hambrey, M.J.; Quincey, D.J.; Glasser, N.F.; Reynolds, J.M.; Richardson, S.J.; Clemmens, S. Sedimentological, geomorphological and dynamic context of debris-mantled glaciers, Mount Everest (Sagarmatha) region, Nepal. Quat. Sci. Rev. 2008, 27, 2361-2389. [CrossRef]

32. Rounce, D.R.; Quincey, D.J.; McKinney, D.C. Debris-covered energy balance model for Imja-Lhotse Shar Glacier in the Everest region of Nepal. Cryosphere 2015, 9, 2295-2310. [CrossRef]

33. MEH Consultants Pvt. Ltd. Detailed Geophysical-ERT Investigation for Structural Design of Imja Lake Lowering, Final Report, Community Based Flood and Glacial Lake Outburst Risk Reduction Project (CFGORRP); United Nations Development Programme: Kathmandu, Nepal, 2014.

34. Rounce, D.R.; Watson, C.S.; McKinney, D.C. Identification of hazard and risk for glacial lakes in the Nepal Himalaya using satellite imagery from 2000-2015. Remote Sens. 2017, 9, 654. [CrossRef] 
35. Digital Globe; Digital Globe: Westminster, CO, USA, 2013.

36. Google Earth; Google: San Bruce, CA, USA, 2015.

37. Digital Globe; Digital Globe: Westminster, CO, USA, 2015.

38. Byers, A.C.; Thakli, S. Khumbu Local Adaptation Plan of Action (LAPA), Sagarmatha National Park and Buffer-Zone, Solu-Khumbu District, Nepal; United States Agency for International Development, Global Climate Change Office, Climate Change Resilient Development Project: Washington, DC, USA, 2015.

39. Google Maps; Google: San Bruce, CA, USA, 2016.

40. Graham, W.J. A Procedure for Estimating Loss of Life Caused by Dam Failure, DSO-99-06; U.S. Department of Interior, Bureau of Reclamation, Dam Safety Office: Denver, CO, USA, 1999.

41. Garcia-Martinez, R.; Lopez, J.L. Debris flows of December 1999 in Venezuela. In Debris Flow Hazards and Related Phenomena; Jakob, M., Hungr, O., Eds.; Springer Science \& Business Media: Berlin/Heidelberg, Germany, 2007; pp. 519-539.

42. CEPAD. Detailed Topographical Surveying and Structural Designing of Imja. Lake Lowering Detailed Design Report (Vol. I: Main Report), Prepared by CEPAD Hydro Consultants (P.) Ltd. For Community Based Flood and Glacial Lake Outburst Risk Reduction Project (CFGORRP); Government of Nepal Ministry of Science, Technology \& Environment Department of Hydrology \& Meteorology: Kathmandu, Nepal, 2015.

43. Keynes, J.M. "Fundamental Ideas" Ch. 4 in A Treatise on Probability; Macmillan: London, UK, 1921; pp. 41-65.

44. Jaynes, E.T. Information Theory and Statistical Mechanics. Phys. Rev. 1957, 100, 620-630. [CrossRef]

45. CIA. The World Factbook, Nepal. Available online: https://www.cia.gov/library/publications/the-worldfactbook/geos/np.html (accessed on 14 April 2017).

46. OMB. Circular A-4, U.S. Office of Management and Budget, Washington, DC. 2003. Available online: https:// www.whitehouse.gov/sites/whitehouse.gov/files/omb/circulars/A4/a-4.pdf (accessed on 14 July 2017).

47. Nepal Rastra Bank. Current Money and Financial Market Rates. Available online: http: / / www.nrb.org.np/cmfmrates_details.php?search=02\&txtyear1=2015\&txtmonth1=01\&txtyear2=2015\& txtmonth2=12\&txtreptype=D (accessed on 16 February 2016).

48. Khanal, N.R.; Koirala, H.; Nepal, P.; Rai, D.; Khanal, B.; Sigdel, S.; Sharma, A.R. GLOF Risk Assessment of the Imja, Tsho Rolpa and Thulagi Glacial Lakes in Nepal; International Centre for Integrated Mountain Development (ICIMOD): Kathmandu, Nepal, 2009; unpublished report.

49. Cropper, M.; Sahin, S. Valuing Mortality and Morbidity in the Context of Disaster Risks, Policy Research Working Papers; No. WPS 4832; World Bank: Washington, DC, USA, 2009.

50. The World Bank. GNI per Capita, PPP. Available online: http://data.worldbank.org/indicator/NY.GNP. PCAP.PP.CD/countries (accessed on 15 February 2015).

51. Sharma, P.; Guha-Khasnobis, B.; Raj Khanal, D. Nepal human development report 2014. Government of Nepal National Planning Commission and United Nations Development Programme: Kathmandu, 2014. Available online: http:/ / www.hdr.undp.org/sites/default/files/nepal_nhdr_2014-final.pdf (accessed on 14 July 2017).

52. Bear River Association of Governments; Bio/West, Inc. Northern Bonneville Shoreline Trail Master Plan; Bear River Association of Governments: Logan, UT, USA, 2002.

53. Trailscape FAQ. Available online: www.trailscapeinc.com/faq.php (accessed on July 18 2017).

54. Charnes, A.; Cooper, W.W.; Rhodes, E. Measuring the efficiency of decision-making units. Eur. J. Oper. Res. 1978, 2, 429-444. [CrossRef]

55. Kuosmanen, T.; Kortelainen, M. Valuing environmental factors in cost-benefit analysis using data envelopment analysis. Ecol. Econ. 2007, 62, 56-65. [CrossRef]

56. Womer, N.K.; Bougnol, M.L.; Dula, J.H.; Retzlaff-Roberts, D. Benefit-cost analysis using data envelopment analysis. Ann. Oper. Res. 2006, 145, 229-250. [CrossRef]

57. USACE-U.S. Army Corps of Engineers: HEC-RAS River Analysis System Hydraulic Users Manual (Version 4.1); Hydrological Engineering Center: Davis, CA USA, 2010.

58. Flo-2D. Flo-2D Pro Reference Manual; FLO-2D Software, Inc.: Nutrioso, AZ, USA, 2012.

59. Lamsal, D.; Sawagaki, T.; Watanabe, T. Digital Terrain Modelling Using Corona and ALOS PRISM Data to Investigate the Distal Part of Imja glacier, Khumbu Himal, Nepal. J. Mt. Sci. 2011, 8, 390-402. [CrossRef]

60. Clague, J.J.; Evans, S.G. A review of catastrophic drainage of moraine-dammed lakes in British Columbia. Quat. Sci. Rev. 2000, 19, 1763-1783. [CrossRef] 
61. Worni, R.; Stoffel, M.; Huggel, C.; Volz, C.; Casteller, A.; Luckman, B. Analysis and dynamic modeling of a moraine failure and glacier lake outburst flood at Ventisquero Negro, Patagonian Andes (Argentina). J. Hydrol. 2012, 444-445, 134-145. [CrossRef]

62. Osti, R.; Egashira, S. Hydrodynamic characteristics of the Tam Pokhari Glacial Lake outburst flood in the Mt. Everest region, Nepal. Hydrol. Process. 2009, 23, 2943-2955. [CrossRef] 